\title{
The Effect of Car, BOPO, NPF, and FDR on Profitability of Sharia Commercial Banks in Indonesia
}

\author{
Saleh Sitompul ${ }^{1}$, Siti Khadijah Nasution ${ }^{2}$ \\ ${ }^{I}$ Department of Accounting, STIE ITMI, Medan, Indonesia \\ ${ }^{2}$ Department of Management Science, Universitas Sumatera Utara (USU) Medan, Indonesia \\ saleh.komeng@gmail.com
}

\begin{abstract}
This study aims to analyze the effect of Capital Adequacy Ratio (CAR), Operational Costs on Operating Income (BOPO), Non Performing Financing (NPF) and Financing to Deposit Ratio (FDR) to Profitability with Return on Assets (ROA) in Indonesian Commercial Banks. The population in this study were 13 Sharia Commercial Banks in Indonesia registered in the Financial Services Authority and Bank Indonesia from 2013-2017, with a total sample of 6 Islamic Commercial Banks. The analytical method used is descriptive statistics, classic assumption tests, and multiple linear regression for hypothesis testing. The results showed partially that the Operational Cost of Operational Income had a significant negative effect on Return on Assets, while the Capital Adequacy Ratio, Non Performing Financing and Financing to Deposit Ratio did not affect Return on Assets of Islamic Commercial Banks in Indonesia. Simultaneously, the Capital Adequacy Ratio, Operational Cost to Operaional Revenue, Non Performing Financing and Financing to Deposit Ratio have a significant effect on Return on Assets of Islamic Commercial Banks in Indonesia. The predictive ability of the four variables on Return on Assets is $82 \%$, while the remaining $18 \%$ is influenced by other factors outside of this research model.
\end{abstract}

Keywords : return on asset; capital adequacy ratio; operating costs on operating income; non performing financing; financing to deposit ratio

\section{Introduction}

Today the community understands and is keen to place funds and in financing its business, the community begins to choose Islamic banks that do not use interest as remuneration but instead use a profit sharing system, so that customers are not charged the same interest every month but the revenue according to the amount of income earned company results. Apart from the reciprocal side of Islamic bank services, it also provides facilities that are different from conventional banks, Islamic banks tend to be more complete because there are social functions not found in conventional banks. Islamic banks also only make halal investments, unlike conventional banks that make halal and illicit investments. This is suitable for the majority of Indonesian people who embrace Islam. One reason people choose Islamic banks is because they are resistant to crises. Indonesia is a country that adheres to an open economic system, therefore Indonesia cannot avoid the global economic crisis that befell almost all countries in the world which began in the second half of 2008. Here, Islamic banks prove better performance that Islamic banks can survive crisis compared to conventional banks. This is because Islamic banks do not deal with foreign exchange much, fluctuating Islamic banks are less affected when compared to conventional banks. 


\section{Review of Literature}

\subsection{Agency Theory (Agency Theory)}

According to Jensen and Meckling proposed by Masdupi (2005: 59) that "agency theory as a relationship between agents (management of a business) and principal (business owner)". In the agency relationship there is a contract whereby one person or more (principal) orders another person (agent) to do a service on behalf of the principal and gives the agent authority to make the best decision for the principal. Information on financial statements delivered in a timely manner will reduce information asymmetry which is closely related to the agency theory (Saleh, 2004: 897). So that in the agency relationship, management is expected to take management policies, especially financial policies that benefit company owners. Of course the owner wants the company to get high profits. If management decisions are detrimental to the owner of the company, agency problems will arise (Islamyanti and Hanafi, 2004: 176).

\subsection{Signaling Theory}

Pramono (2007) states that signal theory indicates the existence of information asymmetry between management and various interested parties, relating to the information issued. Information asymmetry can occur between two extreme conditions, namely small information dissociation that does not affect management. Information asymmetry arises because there is one party that has better information, for example, a manager who knows information about a company's prospects better than its investors. With regard to information asymmetry, it is very difficult for investors and creditors to distinguish between high-quality and low-quality companies. Signal theory suggests how it should give a signal to users of financial statements. Information published is expected to signal the company's financial condition and describe the possibilities that occur related to the debt held.

Profitability shows the company's ability to generate profits for a certain period. Profitability as one of the references in measuring the amount of profit becomes so important to know whether the company has run its business efficiently. Calculation of profitability is done by comparing the company's net income to investment or equity used to obtain the company's profits.

Capital Adequacy Ratio (CAR) is a ratio used to measure a bank's ability to provide minimum capital, which is always maintained as a certain proportion of total weighted assets. According to Dendawijaya (2005: 121), Capital Adequacy Ratio is "the performance ratio of a bank to measure the capital adequacy of a bank to support assets that contain or produce risks, for example loans given". If the CAR ratio is high, then it might be good for the condition of a bank and if the CAR value is high it means that the bank is able to finance its operations. CAR is measured by a certain percentage of RWA (Weighted Analysis by Risk). The minimum capital that must be provided by banks is $8 \%$ and RWA, this has been stipulated in the Bank of International Settlements (BIS) (Kuncoro, 2002: 21).

Operational Cost of Operational Income (BOPO) is a ratio used to measure the level of efficiency and ability of banks to carry out their operations. The main activity of the bank is as an intermediary, namely the collector and distributor of funds to third parties, so the costs and operating income of the bank are dominated by interest costs and interest yields. If there is an increase in operating costs, it will have an impact on the decline in pre-tax profits which will ultimately reduce profitability (ROA) in the bank concerned (Dendawijaya, 2003: 120). 
Non Performing Financing (NPF) is a ratio used to measure the level of efficiency of a bank's ability to conduct its operations. The higher this ratio, it will show the worse the level of efficiency of Islamic banks.

Financing to Defosit Ratio (FDR) or also known as LDR to conventional banks is a ratio used to measure the liquidity of a bank by comparing the amount of credit given to total third party funds. Dendawijaya (2005: 116) states that "lending to credit customers can offset the bank's obligation to immediately meet the demand of depositors who want to withdraw the money that has been used by banks to provide credit". The higher the FDR ratio, the lower the liquidity of Islamic banks.

\section{Research Method}

The research conducted was causal associative research. Causative associative research according to Umar (2002: 30) is "research that aims to analyze the relationship between one variable with another variable or how a variable affects other variables. The population used in this study is Sharia Commercial Banks in Indonesia which are registered with the Financial Services Authority (OJK) and Bank Indonesia. The Islamic commercial banks registered with the Financial Services Authority in 2018 are 13 Islamic banks. The sampling technique used was purposive sampling. Purposive sampling technique, which is by taking samples from the population based on certain criteria so that the sample in this study are as many as 6 Islamic banks.

\subsection{CAR (Capital Adequacy Ratio)}

\section{Results}

From the results of partial test calculations ( $t$ test), obtained tcount of (1.253) with a significance value (0.222). Because the significance value is greater than 0.05 and the tcount (2.327) is smaller than t table (2.05954), the hypothesis $1(\mathrm{H} 1)$ is rejected and means that there is no positive relationship between CAR to the profitability (ROA) of sharia commercial banks. The results of this study are in line with the research conducted by Jannah (2012) but not in line with the research conducted by Suyono (2005), Ruby (2013), Harahap (2014), Maulida (2015), Amelia (2015), and Kusuma (2016 ) where there is a relationship between CAR and the profitability (ROA) of sharia commercial banks.

\subsection{BOPO (Operating Costs on Operating Income)}

From the results of the partial test calculation ( $t$ test), obtained t count of $(-8,784)$ with a significance value $(0,00)$. Because the significance value is smaller than 0.05 and the tcount (8.784) is greater than t table (2.05954), then hypothesis $2(\mathrm{H} 2)$ is accepted and means that there is a negative relationship between BOPO to the profitability (ROA) of sharia commercial banks. The results of this study are in line with the research conducted by Ruby (2013), Harahap (2014), Amelia (2015) and Kususma (2016) but are not in line with the research conducted by Suyono (2005) where there are positive and significant relationships between BOPO variable with Profitability (ROA) of Islamic banks. 


\subsection{NPF (Non Performing Financing)}

From the results of partial test calculations ( $t$ test), obtained tcount of $(1,032)$ with a significance value $(0,312)$. Because the significance value is greater than 0.05 and the tcount (1.032) is smaller than t table (2.05954), then hypothesis 3 (H3) is rejected and means that there is no negative relationship between NPF to the profitability (ROA) of sharia commercial banks. The results of this study are in line with the research conducted by Suyono (2005), and Kusuma (2016) but the results of this study are not in line with the research conducted by Ruby (2013), Harahap (2014), and Amelia (2015) wherein the results of the research are negative relationship between NPF variables on Islamic banks' profitability (ROA).

\subsection{FDR (Financing to Deposit Ratio)}

From the results of partial test calculations ( $t$ test), obtained tcount of $(1,872)$ with a significance value $(0,073)$. Because the significance value is smaller than 0.05 and the tcount (1.872) is smaller than t table (2.05954), then hypothesis $4(\mathrm{H} 4)$ is rejected and means that there is no positive relationship between NPF to the profitability (ROA) of sharia commercial banks. The results of this study are in line with the research carried out by Jannah (2012), Maulida (2015) and Kusuma (2016) but the results of this study are not in line with the research conducted by Ruby (2013) wherein the results of the research indicate a positive and significant relationship between variables FDR against profitability (ROA), besides Harahap (2014), and Amelia wherein the results of his research show that there is a negative relationship between the variable BOPO and the profitability (ROA) of sharia commercial banks.

Based on the results of testing the research variables simultaneously indicate that the Capital Adequacy Ratio, operational costs to Operating Income, Non Performing Financing, and Fianancing to Deposit Ratio have a significant effect on Return On Assets (ROA) which is indicated by a significance value $F<0.05$ with $F$ value significance of 0,000 . Through the $F$ test for simultaneous testing, obtained a value of Fcount $(28,420)$ with a significance value $(0,000)$. Because the significance value $(0.00)$ is smaller than 0.05 and the calculated value (28.420) is greater than Ftable (2.76), then hypothesis 5 (H5) is accepted and means that the independent variable is CAR (Capital Adequacy Ratio), BOPO (Operating costs for Operating Income), NPF (Non Performing Financing), and FDR (Financing to Deposit Ratio), are significant explanations and simultaneously affect the dependent variable, namely the profitability (ROA) of Islamic banks.

\section{Conclusion}

Capital Adequacy Ratio (CAR), Operating Costs to Operating Income (BOPO), Non Performing Financing (NPF), Financing to Deposit Ratio simultaneously have a significant effect on Return On Assets (ROA). This research is in line with the research conducted by Suyono (2005), Jannah (2012), Rubby (2013), Harahap (2014), Maulida (2015), Amelia (2015) and Kusuma (2016). Partial Capital Adequacy Ratio (CAR) does not significantly influence Return On Assets (ROA). This research is in line with research conducted by Jannah (2012) but is not in line with the research by Suyono (2005), Ruby (2013), Harahap (2014), Maulida (2015), Amelia (2015), and Kusuma (2016). Operational Costs to Operational income (BOPO) partially have a significant negative effect on Return On Assets (ROA). This research is in line with research conducted by Ruby (2013), Harahap (2014), Amelia (2015) and Kususma (2016). but it is not in line with the research conducted by Suyono (2005). Partially Non Performing 
Financing (NPF) does not significantly influence Return On Assets (ROA). This research is in line with the research conducted by Suyono (2005), and Kusuma (2016) but the results of this study are not in line with the research conducted by Ruby (2013), Harahap (2014), and Amelia (2015). Partial Financing to Deposit Ratio (FDR) does not significantly influence Return On Assets (ROA). This research is in line with research conducted by Jannah (2012), Maulida (2015) and Kusuma (2016) but the results of this study are not in line with the research conducted by Ruby (2013). The test results of the determination coefficient show the adjusted $\mathrm{R} 2$ value with the $\mathrm{R}$ square number of 0.820 which means that the ability of independent variables (CAR, BOPO, NPF, and FDR) in explaining the dependent variable profitability proxied by ROA is $82 \%$. While the remaining $18 \%$ is explained by other variables not examined in this study.

\section{References}

Amelia, Erika, 2015. Financial Ratio and Its Influence to Profitability in Islamic Banks, Al-Iqtishad, Volume 2, Hal 229-240.

Antonio, muhammad Syafie i. 2001. Bank Syariah Dari Teori ke Praktik. Gema Insani Press. Jakarta.

Bank BCA Syariah, 2018. Publikasi Laporan Keuangan Tahunan. http://www.bcasyariah.co.id/ (25 Mei 2018)

Bank BNI Syariah, 2018. PublikasiLaporan Keuangan Tahunan. http://www.bnisyariah.co.id/ (25 Mei 2018)

Bank BRI Syariah, 2018. Publikasi Laporan Keuangan Tahunan. http://www.brisyariah.co.id/ (25 Mei 2018)

Bank Mega Syariah, 2018. Publikasi Laporan Keuangan Tahunan. http://www.megasyariah.co.id/ (26 Mei 2016)

Bank Muamalat, 2015. Publikasi Laporan Keuangan Tahunan. http://www.bankmuamalat.co.id/ (26 Mei 2016)

Bank Syariah Mandiri, 2015. Publikasi Laporan Keuangan Tahunan. http://www.syariahmandiri.co.id/ (26 Mei 2016)

Dendawijaya, Lukman, 2000. Manajemen Perbankan, Ghalia Indonesia, Jakarta.

Dewan Syariah Nasional majelis Ulama Indonesia, 2003. Fatwa DSN Nomor: 20/DSN-MUI/IV/2001. Jakarta.

Ghozali, Imam. 2005. Aplikasi Analisis Multivariate dengan program SPSS, Badan Penerbit Universitas Diponegoro, Semarang.

Hasibuan, H. Melayu S. P. 2007. Dasar-Dasar Perbankan, PT. Bumi Aksara, Jakarta.

Rivai, Veithzal dan Arvian Arifin, 2010. Islamic Banking : Sebuah Teori, Konsep, dan Aplikasi, Bumi Aksara, Jakarta.

Saleh, Rahmad, 2004. "Studi Empiris Ketepatan Waktu Pelaporan Keuangan Perusahaan manufaktur di Bursa Efek jakarta”, SNA VII, Denpasar.

Sugiono, 2004. Metode Penelitian Bisnis, CV. Alfabeta, Bandung.

Sunyoto, Danang, 2009. Analisis Regresi dan Uji Hipotesis, $1^{\text {st }}$ Edition, Media Pressindo, Yogyakarta.

Surat Edaran BI No, 3/30/DPNP, on 14 December 2001. Tentang Perhitungan Rasio Keuangan. 